\title{
Encouraging Reflection and Critical Friendship in Pre- service Teacher Education
}

BRANKO BOGNAR $^{* 1}$ AND IRENA KRUMES ${ }^{2}$

$\approx$ Reflectivity is an important professional competence of contemporary teachers. In order to explore how to encourage students' reflection, we conducted a two-year action research project impelling them to become mutual critical friends. For critical friendship communication and other project activities, we utilised Moodle - an online learning management system. On the basis of the analysed data that were gathered at the end of each action research cycle, we determined that the students felt comfortable in the role of critical friends and that critical friends' reflections were particularly pleasant for them. They experienced the comments of their critical friends as friendly, encouraging, useful, specific, interesting, detailed, positive, professional and clear. The majority of students (91\%) think that the critical friendship discussion should be continued within the course Correlated-integrated systems in Croatian language teaching, and $85 \%$ of them suggest introducing this approach in other teachers' education courses. We determined that the technical mode of reflective thinking prevails in the students' correspondence. The practical or contextual level could rarely be observed while critical reflection was completely absent in 11 of 14 discussions. Reflective thinking of students (future teachers) should be fostered from the beginning of their studies within various courses, particularly in the pedagogical and methodological ones. To encourage their students to be critically reflective, university teachers should embrace reflective thinking by becoming critically-reflective practitioners and conducting action research in their teaching practices.

Keywords: action research, critical friendship, critical reflection, reflection in teacher education, reflection through online discussion

$1{ }^{\star}$ Corresponding Author. Josip Juraj Strossmayer University in Osijek, Faculty of Education, Croatia; branko.bognar@gmail.com.

2 Josip Juraj Strossmayer University in Osijek, Faculty of Education, Croatia. 


\section{Spodbujanje refleksije in kritičnega prijateljstva $\mathrm{v}$ začetnem izobraževanju učiteljev}

Branko Bognar In Irena Krumes

$\approx$ Reflektivnost je pomembna strokovna kompetenca sodobnih učiteljev. Z namenom ugotavljanja, kako spodbujati refleksijo študentov, smo izvedli dveletno akcijsko raziskavo, v okviru katere smo študente spodbujali, da prevzamejo vlogo kritičnih prijateljev. Za komunikacijo med kritičnimi prijatelji in za druge projektne aktivnosti je bil uporabljen Moodle spletna učilnica oz. učno orodje. Na osnovi analiziranih podatkov, ki smo jih zbrali na koncu vsakega akcijsko raziskovalnega cikla, smo ugotovili, da so se študentje dobro počutili v vlogi kritičnih prijateljev in da so bile refleksije kritičnih prijateljev za njihovo učenje spodbudne. Komentarje kritičnih prijateljev so izkusili kot prijateljske, spodbujajoče, uporabne, konkretne, zanimive, podrobne, pozitivne, strokovne in jasne. Velika večina študentov ( $91 \%)$ je menila, da bi se morala razprava kritičnega prijateljstva nadaljevati v okviru predmeta sistemi korelacije in integracije pri pouku hrvaškega jezika, $85 \%$ pa jih je predlagalo uvajanje tega pristopa v druge predmete pedagoškega izobraževanja. Ugotovili smo, da v komunikaciji med študenti prevladuje tehnična raven refleksije. Praktično ali kontekstualno raven smo zasledili redko, medtem ko je bila raven kritične refleksije popolnoma odsotna $v$ enajstih izmed štirinajstih razprav. Reflektivno mišljenje študentov (bodočih učiteljev) bi morali spodbujati od začetka njihovega študija $\mathrm{v}$ okviru različnih predmetov, zlasti v okviru pedagoških in specialnodidaktičnih. Da bi visokošolski učitelji spodbudili svoje študente h kritični reflektivnosti, bi morali sami postati kritično-reflektivni praktiki in v okviru svojega poučevanja izvajati akcijsko raziskovanje.

Ključne besede: akcijsko raziskovanje, kritično prijateljstvo, kritična refleksija, refleksija v izobraževanju učiteljev, refleksija v okviru spletne razprave 


\section{Introduction}

Reflective thinking in education has its theoretical roots in Dewey's seminal work How We Think. He asserts that active, persistent, and careful consideration of any belief or supposed form of knowledge in the light of the grounds that support it, and the further conclusions to which it tends, constitutes reflective thought' (Dewey, 1910, p. 6). Thus, according to Dewey, reflective thinking does not accept any thought or belief without questioning different options. There is no consensus regarding a distinction between critical and reflective thinking. Some authors use the terms synonymously (Porntaweekul, Raksasataya, \& Nethanomsak, 2015). Some hold critical thinking as a type of reflective thinking (Ennis, 1993), while others claim that critical thinking represents a higher level of reflective thinking (Phan, 2010).

However, the uncritical approach is based on the assumption that, in one's social as well as professional life, it is possible to predict most phenomena and prepare appropriate procedures for successfully controlling them. In a static society, with slow changes, such a presumption sounds somewhat meaningful. In a postmodern, democratic, pluralistic, fast-changing society, reflective thinking is essential.

Shandomo (2010, p. 103) thinks that 'reflective thinking leads educators to act deliberately and intentionally rather than randomly and reactively'. It is hard to develop reflective thinking in future teachers if they are expected to repeat the 'right' answers they learnt from their teachers or read in literature. To develop reflectivity, it is important that students have sufficient opportunities to think on their own. Their professors could help them only if they developed reflective thinking themselves, particularly critical thinking (Choy \& Oo, 2012). Unfortunately, Schön (1987) determined that technical rationality prevails rather than reflective practice at the university. It is common for this approach to firstly teach students 'the relevant basic science, then teach them the relevant applied science, and finally, a practicum in which students are presumed to learn to apply research-based knowledge to the problems of everyday practice' (Schein, 1973, as cited in Schön, 1987, p. 8). This gives future teachers the false impression that universal teaching methods do exist, and they simply must learn and apply them in practice. If a problem occurs, it is mostly attributed to the student's lack of knowledge in properly applying teaching methods. Very rarely are the observed problems carefully analysed with an aim to better understand the specific situation in which they appeared in order to find the most appropriate, rather than universal solutions.

Instead of technical rationality, Schön (1983) emphasises reflective 
practice, in which practitioners reflect on spontaneous solutions they devised in specific professional situations. A teacher who reflects-in-action:

...becomes a researcher in the practice context. He is not dependent on the categories of established theory and technique, but constructs a new theory of the unique case. His inquiry is not limited to a deliberation about means which depends on a prior agreement about ends. He does not keep means and ends separate, but defines them interactively as he frames a problematic situation. (Schön, 1983, p. 68)

The model of reflectivity devised by Argyris and Schön considerably contributed to the affirmation of the reflective approach in education and other professional fields. The main purpose of their reflective model was enabling higher professional effectiveness. They stated 'we cannot be effective over the long run unless we can learn new ways of managing existing governing variables when conditions change. In addition, we cannot be effective unless we can learn new governing variables as they become important' (Argyris \& Schön, 1975, p. 24). However, social problems cannot be reduced to the issue of the professional effectiveness of practitioners and their organisations. Social problems have deeper roots. Habermas believes that the root of social irrationality is that the majority of people are not able to participate consciously in the creation of history.

A rationalization of history cannot therefore be furthered by an extended power of control on the part of manipulative human beings, but only by a higher stage of reflection, a consciousness of acting human beings moving forward in direction of emancipation. (Habermas, 1974, p. 276)

The higher level of reflection is enabled by critical reflection through questioning the elementary character of capitalistic society (Brookfield, 2010) in which capital plays the key role, not people (Horkheimer, 1989). The main purpose of critical reflection 'is the allowing of more control and choice in individual lives through the exposure of dominant social assumptions' (Fook \& Askeland, 2006, p. 53). Unlike reflective practice that stays on the level of finding effective ways for improving the functioning of the organisation, critical reflection questions the socio-political context in which the practice is carried out. It challenges taken-for-granted beliefs, values and dominant ideologies (Brookfield, 2005; Vince \& Reynolds, 2009), power relationships (Fook, 2015), and highlights the possibilities of the emancipation and the social changes (Habermas, 1974; Mezirow, 2000). In schools 'reflective teachers are skilled at analyzing micro-level classroom contexts...' while 'critically reflective teachers have an elevated sense of social responsibility to address and tackle inequities 
in and out of their classrooms to ultimately situate their individual actions and beliefs within larger sociopolitical contexts' (Hernandez \& Endo, 2017).

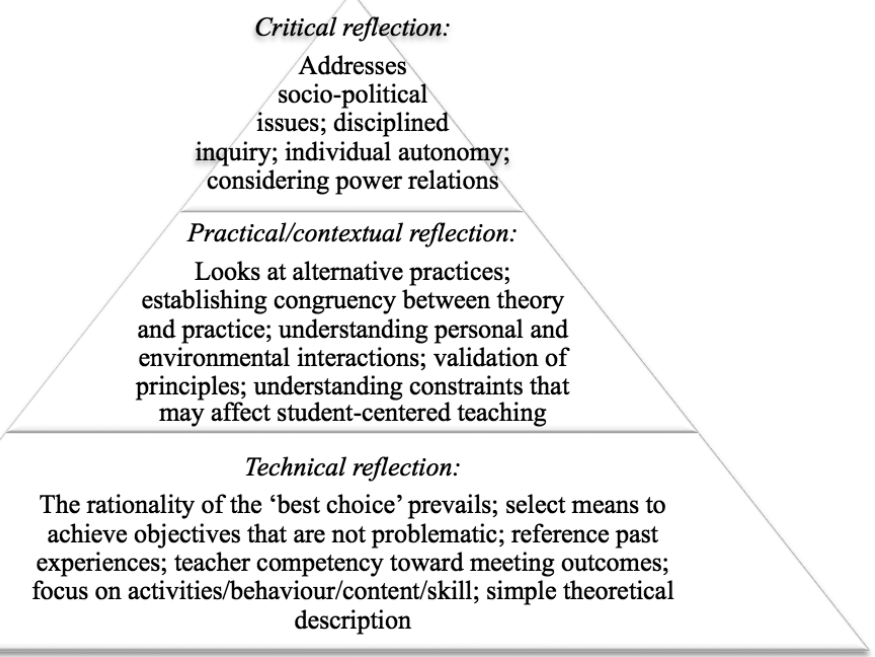

Figure 1. Modes of reflective thinking (van Mannen, 1977; Taggart \& Wilson, 2005)

The reflectivity of practitioners can be realised on several levels. Starting from Habermas's (1971) three categories of knowledge and human interests (technical, practical, and emancipatory), Van Mannen (1977), made a distinction between technical, practical, and critical levels of reflectivity (Figure 1). However, it is possible to omit the reflective level, i.e. the absence of thorough thinking and comprehending of the relevant terms, theories and teaching practice.

On the technical level, teachers do not inquire about aims. They only evaluate 'the effectiveness of their practice in achieving aims' (Carr \& Kemmis, 1986, p. 30). Practical reflection implies examining complex conditions in which practice takes place. On this level, reflection means the reconciliation of theory and practice. However, practical reflection deals merely with what occurs in a specific professional context. In contrast, critically-reflective teachers are aware that the education system is just one of the social structures that often serves 'to reproduce economic inequality and to distort personal development' (Bowles \& Ginits, 2007, p. 66). Critical reflection is focused on the disclosure of myths, that is, dominant ideologies supported in schools to legitimate social inequalities (Haralambos \& Holborn, 2002). In addition to his critique of ideology, Brookfield (2005) finds important to contest hegemony. He considers that 
hegemony to be 'the process by which we learn to embrace enthusiastically a system of beliefs and practices that end up harming us and working to support the interests of others who have power over us' (p. 94). To be able to take a stand it is necessary that adults critically examine everything they have previously uncritically accepted in the course of their socialisation. Mezirow (2000) suggests that adult education in democratic societies should enable students to 'become more aware of the context of their problematic understandings and beliefs, more critically reflective on their assumptions and those of others, more fully and freely engaged in discourse, and more effective in taking action on their reflective judgments' (p. 31).

It is possible to utilise various tools and techniques in written and spoken form to encourage students' reflectivity. These include critical incident technique (Brookfield, 2006; Griffin, 2003), journaling (Boud, 2001; Scales, Briddon, \& Senior, 2013), logs and diaries (Nadin \& Cassell, 2006; McNiff \& Whitehead, 2010), (electronic) portfolios (Lewis, 2015), on-line discussions (Tsang, 2011; Whipp, 2003), reflective or critical conversations (Chambers, Colombo, Askland, \& Clarke, 2003), narratives or stories (Craig, 2009), and creative representations like poetry, pictures, and videos (Smith, 2010). Fook and Gardner (2006) point out that the tools and techniques are not as important in developing reflectivity as the organisational culture is. Organisational culture comprises norms, values, customs, history, relations between people, climate, embedded skills, symbols, rituals and celebrations (Schein, 2010; Stoll, 1998). In order to become prominent reflectivity has to permeate all core elements of the organisational culture. This implies a shared sense of its importance and the knowledge of how to use it on a daily basis. Therefore, reflectivity is not an occasional activity; it is more a 'part of the routine, normative demands of students' (Gay \& Kirkland, 2003, p. 184).

In implementing the reflective approach in prospective teachers' education, it is possible to apply critical friendship. Costa and Kallick define a critical friend: as a trusted person who asks provocative questions, provides data to be examined through another lens and offers critiques of a person's work as a friend. A critical friend takes the time to fully understand the context of the work presented and the outcomes that the person or group is working toward. The friend is an advocate for the success of that work. (Costa \& Kallick, 1993, p. 50)

Critical friendship could be established in face-to-face communication after finished lessons, as well as by using on-line applications. Conducting distant, critical friendship on web-based forums is particularly convenient (Vidović \& Kuharić Bučević, 2013). In that way, critical friends do not lean only 
on their memories, but can integrate data from different sources into their discussions.

To support the reflective practice of practitioners, it is important to establish cooperative conditions and to achieve open and well-intentioned communication about problematic aspects of practice. MacKnight (2000) points out: 'It is unlikely that students will succeed in substantive, reflective exchanges if they have not learned to carry on similar conversations elsewhere.' He suggests starting with 'some off-line activities that will give students a better understanding of the collaborative learning and communication process' (p. 39). The reflective communication could be continued online. To encourage critical reflection, it is important to create conditions for participants to have the opportunity in smaller groups to freely discuss their own experiences within a broader social context (Fook \& Askeland, 2007). Discussions on the forum can enable this if the dominant role of teachers is abandoned (Harrington \& Hathaway, 1994).

\section{Method}

In this study, we applied action research as a research design. Furthermore, we embraced the ideas of critical action research (Kemmis, McTaggart, \& Nixon, 2014) in which teachers attempt 'to organize themselves into communities of researchers dedicated to emancipatory experience for themselves and their students' (Kincheloe, 1995, p. 74).

The inquiry was conducted within the course Correlated-integrated systems in Croatian language teaching as a part of the university study programme for teacher education during two academic years (2014/15 and 2015/16). Students attend this course in the second semester (April to June) in their final (fifth) year of university studies. Every second week, students had four lessons (4×45 minutes). The second author of this article was a teacher and co-researcher while the first author participated in administering the Moodle course (http://pedagogija.net) and in collecting and analysing data.

We initiated this action research due to our dissatisfaction with the students' reflections on their own lessons in the course Practicum in teaching methodology of the Croatian language. Students attend this course in their fourth year of studies. A student who taught a lesson must comment on it, and then her or his colleagues offer their reflections. We observed that they usually hesitate to openly discuss observed problems to avoid spoiling good relationships. Some of them are not able to observe problems because of a lack of theoretical knowledge and some only repeat the professor's comments. All of that indicated the necessity for the improvement of students' reflective thinking. 
The reflective approach that we intended to use in this research required the teacher to introduce changes into her teaching practice and to encourage students to study literature independently in order to participate in online discussions presenting well-reasoned and supported arguments. There were also changes in the use of Moodle, which was previously used as a file repository for the assigned literature for students. Instead of learning that was based on reading literature, we decided to enable students to use online forums for their reflective discussions before and after workshops that they planned and conducted working in teams. It was feasible since the open source learning management system Moodle enables the social constructivist online learning which puts 'a focus on collaborative discourse and the individual development of meaning through construction and sharing of texts and other social artefacts' (Dougiamas \& Taylor, 2003).

There are several reasons why we chose online discussion forums to encourage students' reflectivity. First, in the classroom teaching, there is a lack of time to enable all students to participate in face-to-face reflective discussions. We were acquainted with the research results which showed that, compared to face-to-face discussions, 'participants in networked collaboration could use more deep-thinking strategies like exchanging more ideas, proposals, and perspectives. Conversational analyses showed that students felt freer to have reflective time and to take issue with different perspectives' (Cho \& Schunn, 2003, p. 247). In addition, we considered that the members of Generation Y (Tsang, 2011) or 'digital natives' (Prensky, 2001) should be given the opportunity to learn in their natural environment. Finally, the first author had previous experiences in organising online discussions (Bognar, Gajger, \& Ivić, Constructivist e-learning in higher education, 2016) and creating online communities of critical friends (Bognar \& Mompoint-Gaillard, 2017).

Our intention was to affirm cooperation, creativity, and reflectivity in our practice. The reason for accentuating those values lies in the fact that the quality of the teachers depends considerably on creating an organisational culture in which they collaboratively reflect on the impacts of their practice on students' learning (Hattie, 2015). They take time to create and 'test new teaching methods and to receive follow-up support and coaching in their classrooms as they faced problems of implementing changes...' They participate in the reflective communities of practice that leads them 'to deprivatise their practice and gain feedback about their teaching from colleagues' (Ingvarson, Meiers, \& Beavis, 2005, pp. 15-16). Therefore, we did not expect students to follow prescribed pedagogical scenarios; on the contrary, it was our intention to encourage their cooperatively devised creative solutions while engaging their reflectivity. The main purpose of our action research was encouraging reflectivity in students impelling them to 
become mutual critical friends in the online discussion forums. It implied encouraging cooperative learning, students' creativity and their reflectivity (Table 1).

Table 1

Aims and criteria of action research

\begin{tabular}{ll}
\hline Aims/values & Criteria \\
\hline Encouraging cooperative learning & $\begin{array}{l}\text { Students working in teams independently define workshop } \\
\text { topics and plans, and realise them }\end{array}$ \\
\hline Fostering creativity in students & $\begin{array}{l}\text { Students conduct original teaching activities that are appro- } \\
\text { priate for workshop topics }\end{array}$ \\
\hline Encouraging their reflectivity & $\begin{array}{l}\text { Most students can write their comments in the online discus- } \\
\text { sion forums at the technical level } \\
\text { In most teams, a practical level or reflection is observed, and } \\
\text { in some discussions critical reflectivity is determined }\end{array}$ \\
\hline
\end{tabular}

At the beginning of the semester, we discussed our action research plan with each group of students. In addition, we asked them to confirm their willingness to participate and to give written consent for photos and videos of their workshops to be taken and published on Moodle, YouTube, and in a scientific publication. We also explained to them how to use Moodle for critical friendship. Since students had already participated in a similar activity that was organised in the course Methodology of Pedagogical Research in the previous semester, most of them did not have any problem using Moodle. In the first action research cycle, all 27 students took part in the discussions before conducting a workshop, while 23 took part in the discussion after the workshop. The next year, 24 of 26 students enrolled in Moodle while in the second round of discussion there were 22 participants.

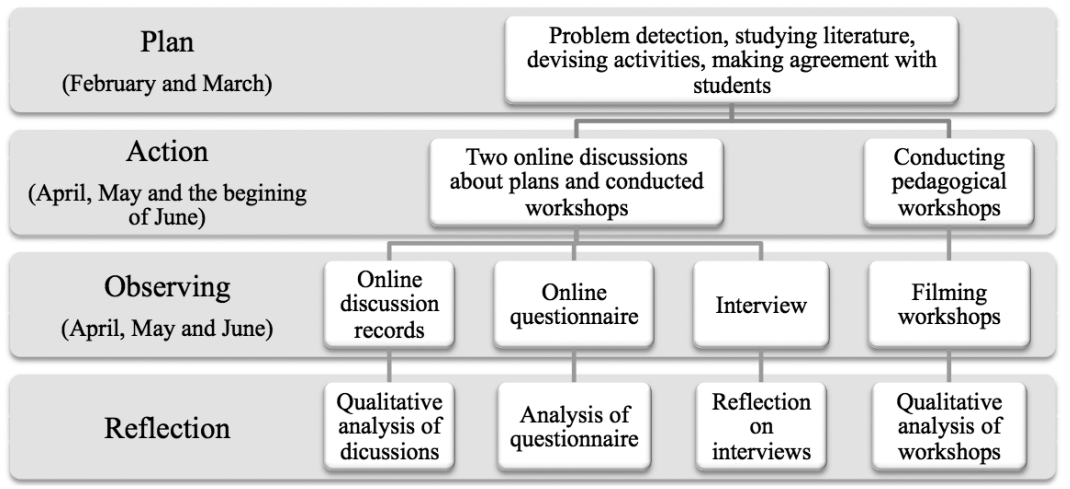

Figure 2. Action research stages 
Our action research project consisted of the usual stages: planning, action, observing and reflection (Carr \& Kemmis, 1986; Kemmis, McTaggart, \& Nixon, 2014). These stages were repeated both academic years in a similar manner (Figure 2). In the first year (2015) planning lasted longer (February and March) since we had to develop the whole project. In March of the following year, we slightly revised the initial plan according to the results of the reflection in the first project cycle. These changes referred to students' freedom to choose topics of their pedagogical workshops, the workshop venue, and the duration of students' discussions.

With the aim of monitoring and evaluating the changes, we organised students' correspondence in forums, videos, and photos of workshop activities, administered the post-Moodle questionnaire at the end of each academic year and carried out recorded interviews with both groups of students. The most important data source was students' correspondence recorded on Moodle forums. To conduct a qualitative content analysis of the critical friendship discussions on Internet forums, we determined three modes of reflection: technical, practical or contextual, critical and absence of reflection (Figure 1). In addition to correspondence, we obtained vital feedback from the students by using the online questionnaire. It comprised 20 questions. We posed open-ended questions to find out what students learned, what they consider the advantages or disadvantages of the critical friendship discussions and how to improve it all. Likert scale questions helped us to measure the fulfilment of students' expectations, their feelings in the role of critical friends, etc. Semantic differential was used to obtain feedback about critical friends' comments. There were also two dichotomous questions about using online critical friendship discussions in the course Practicum in teaching methodology of the Croatian language and in other courses. We utilised QDA Miner Lite software to conduct qualitative analysis of students' correspondence on forums and open-ended responses in the online questionnaire. MS Excel aided in conducting quantitative data analysis of online questionnaire. At the end of each cycle, the second author conducted the group interviews to find out more information about expectations, advantages, and disadvantages of this experience. Videos aided in determining how many original teaching activities students organised in their workshops.

We conducted an exhaustive analysis, critical reflection and interpretation of all data at the end of our research. Considering that both cycles had the same aims and almost identical structure, the results and discussion are elaborated on in the next chapter. 


\section{Results and Discussion}

\section{Description of Students' Classroom Activities and Activities on the Online Forum}

At the beginning of the semester, the students were divided into teams consisting of two to five members with the task of preparing classroom activities and presenting their plans on Moodle web forums that were created for that purpose. For the workshops that they were preparing, it was necessary to establish integration, correlation, and coordination of the contents of different courses (Težak, 1996). During that process, the focus was on the logical interconnection of similar subjects (the Croatian language, Music, and Art) with the goal on integrating classroom activities into the pupils' cognitive, affective, and life experience (Rosandić, 2005). Students were supposed to organise their classroom activities in the form of a pedagogical workshop in which individual tasks and cooperative activities may rotate and which are based on holistic and experiential learning. Thus, some scenarios could 'incorporate dance, play, and division of larger groups into two or three smaller teams that could work in separate rooms or at separate tables in the same classroom' (Bognar \& Matijević, 2002, p. 249).

During the lectures that were held at the faculty, students were informed about the criteria for the evaluation of their discussion that included the amount of written text, elaboration and realisation of the presented ideas, as well as the number of relevant literature they quoted. Additionally, the students were presented and familiarised with the basic theoretical foundations of the correlated-integrated system. These theoretical foundations could be expanded upon by reading the suggested literature that was available in a digital format on the Moodle file repository, after which students could check their knowledge by completing a quiz on Moodle. Furthermore, with the use of photographs, students were shown examples of pedagogical workshops from the previous academic year (2014/15), while in the following academic year (2015/16), video recordings of the best pedagogical workshops from the preceding year were shown. Moreover, students were expected to write a critical review of one of the previous year's workshops, whose video recordings were available on Moodle (https://youtu.be/Hz7NzmVoLFA, https://youtu.be/sNTbhvqPGd4³).

After that, the teams started planning their classroom activities. First, they had to independently choose the topics for their workshops. In the first year, there were no limitations on choosing the topic so they were very different

3 The first video recording was filmed by the teacher, and the other video recordings were filmed by the students who conducted the pedagogical workshops. 
from each other (e.g. The Sun, What Can I Do for My Health, Stop Smoking, The International Day of Families). In the next year, students were advised to focus their topics on well-known fairy tales so some of the topics were: Love (Little Mermaid, H. C. Andersen), The role of women in society (Cinderella, Jacob and Wilhelm Grimm), Stribor's Forest, (I. Brlić Mažuranić), Moral values (Little Prince, A. de Saint-Exupéry).

The teams then had to design their own pedagogical workshops. Previously, students had to study the teaching curriculum and the relevant literature for their workshops. They were asked to upload the workshop plans on Moodle forum so that other critical friends could take part in the discussion. The structure for the critical friendship was circular, i.e. the members of the first team were critical friends to the second team, the second team to the third team and so forth. Some teams developed a lively discussion that helped in preparing workshops:

Dear Colleagues of the 'Dream team', my team and I are delighted that you have actively taken part in our [discussion about the] thematic network. Some of your suggestions have prompted us to further think about some of our planned activities. We were talking today about your suggestions and our initial ideas. I like this online type of work, it achieved its purpose, and with your suggestions, you have encouraged us to change some of our classroom activities. I can say that the traditional saying still holds: 'Two heads are better than one', but in our case it is that eight heads are better than four. ;) (Student I.S., personal communication, April 28, 2016)

In the first year, some workshops were carried out in schools with pupils, and some were carried out at the faculty with other students. Some of the workshops were planned and carried out very well, particularly those that were carried out at the faculty. For that reason, we have decided that next year students should carry out their workshops at the faculty, with their colleagues as participants of the workshops. Aside from that, a smaller number of teams were formed (six, as opposed to eight from the previous year), and more time was allocated for discussion of the realised workshops.

Through the analysis of video recordings of the second year, we have observed that the workshops were organised very similarly. It was evident that students had been using an existing workshop design to plan and create their own workshops. However, there were numerous creative solutions. During the first year of our research, the analysis of video recordings showed 22 original activities in eight teams. The next year there were 23 original activities in six workshops. 


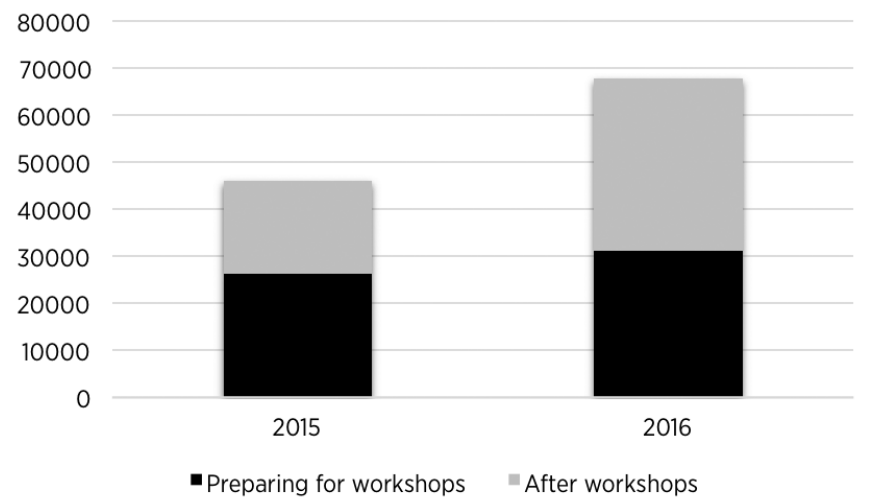

Figure 3. Student activity during the first and the second year of research expressed by the numbers of words written in the online forums

After finishing their workshops, each team uploaded an abridged video recording of them, which initiated the forum discussion. Based on the total number of words (Figure 3) written in the discussion it is evident that there is an increase in activity in the second year of the research. This particularly refers to the discussion at the end of the realised workshops where students were given more time (two weeks instead of one).

\section{Analysis of the Evaluation Questionnaire}

At the end of each research cycle, we asked the students to fill out an anonymous evaluation questionnaire that was available on Moodle. The total number of the respondents who completed the questionnaire was 46,22 students $(81.5 \%)$ involved in the first year of research and 24 (100\%) students who participated in the second year of research.

All students answered the question related to the expectations of the discussion on the web forum. The majority $\left(32^{4}\right)$ expected assistance and useful pieces of advice for the planning and realisation of the workshops. Likewise, students expected friendly and honest feedback (19), new ideas, learning and development of competencies (8), understanding and respecting other opinions (8), active and prompt student involvement (7), cooperation ( 7 ), discussion similar to the one in Methodology of pedagogical research ${ }^{5}$ (2), support and

4 Numbers in parentheses denote the frequency of categories that were determined based on the qualitative analysis of students' answers to the open-type questions. Due to their complexity, the students' answers were divided into smaller parts and assigned to different categories. Therefore, the total sum of frequencies is higher than the number of students who had completed the questionnaire. This refers to all the open-type questions.

5 Students attended that course the previous semester, and the lectures were held by the first author of this article. 
praise (2), pleasant communication (1), stimulating thinking (1), fewer tasks related to critical friendship (1), earlier beginning of the discussion (1), and more in-person discussions (1).

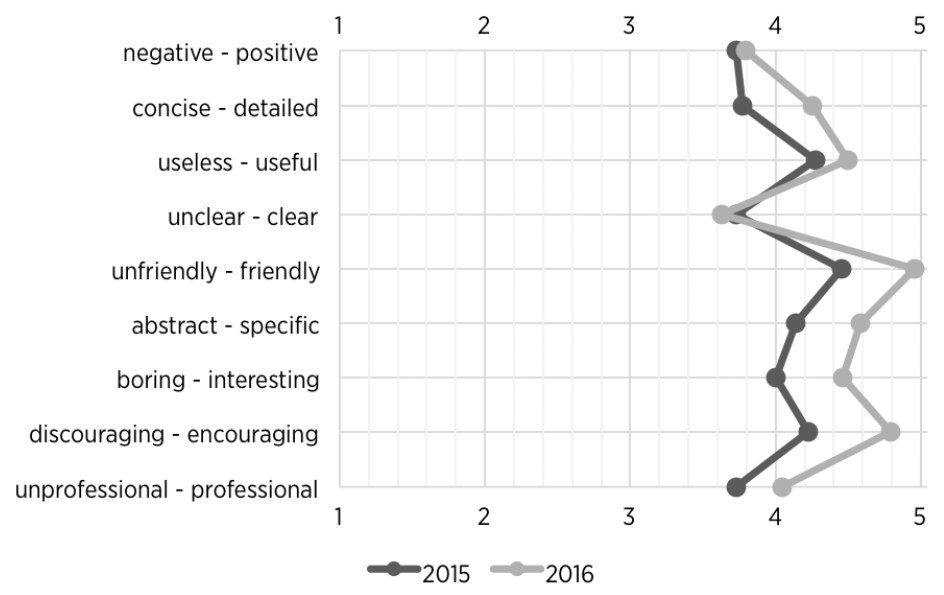

Figure 4. Results of semantic differential in relation to the assessment of the critical friends' comments

To determine how the students experienced the comments given by their critical friends, they were offered nine contrasting adjectives with a fivestage scale (Figure 4 ). Students perceived their critical friends' comments as mostly friendly (4.7), encouraging (4.5), useful (4.4), specific (4.4), interesting (4.2), detailed (4), professional (3.9), positive (3.8) and clear (3.7).

All students answered the question relating to what they learned by participating in critical-friendly discussions. They pointed out receiving and giving constructive critical comments (35) as well as cooperative learning (5). Several students wrote that they learned how to think critically (4), to organise new classroom activities (4), to understand others and their practice (3), to express themselves better (1), to be more open to change (1) and to be a critical friend (1).

All students responded to questions about the advantages and disadvantages of online discussion and gave suggestions for improvements. They reported that the advantages were the possibility to exchange ideas, pieces of advice, suggestions and experiences (16), to self-evaluate and to evaluate others, and to give and receive feedback (12). They emphasised the freedom of choosing the time and place to participate in debates (11), the freedom of expression and respect for different opinions ( 7 ), and the formation of cooperative, friendly 
relations and the possibility of learning in a community of critical friends (10). Students also emphasised the mutual assistance, motivation, support, praise and encouragement (9) as well as positive and well-intentioned critical comments ( 7 ). Some of the students stated that they had enough time to think, read literature and to re-read everything that was written on the forum in detail (7). Lastly, some students were encouraged to think critically (8), to think creatively (2), and to cooperate with others to find solutions to problems (5) by participating in a lively discussion with other participants on the forum (6).

The biggest disadvantages of the online forum discussions were the misunderstandings and the problems in communication that occurred because of the lack of personal communication (22). Moreover, this type of online discussion requires a lot of time (16). Part of the participants pointed out that long comments could be difficult to follow and comment on (11). It could also be observed that there was an insufficient and uneven involvement on the part of some of the students (5), repetition of what has already been written (5), and worrying about the word count and the required literature for the evaluation criteria of the discussion (5). Apart from that, it has also been noted that some students found the web forum confusing and that it was difficult to express themselves in written form (3), while others complained about the necessity of being dependent on the activity of others in the discussion (2), and that some students did not accept their colleagues' advice and comments (2).

As a proposal for improving the online discussion on the web forum, participants suggested some changes in the evaluation criteria for the discussion (17). This particularly refers to the word count and the number of works cited in the text. Students feel that evaluation should be focused more on the quality, rather than the quantity of the comments. It was also proposed that the comments should be shorter (4) and that the time limitation for the discussion should be omitted (4). The participants are of the opinion that the discussion should be a combination of both online and in-person communication (9). Students suggested that alongside the written discussion on the web forum, which is a type of asynchronous communication, there should also be chats and video conferences (3). Furthermore, the use of emoticons was proposed (1) in order to better understand the feelings of the person writing the comment. One student suggested that her colleagues should be even more engaged in intensive critical thinking, and another her colleagues put forward a proposal that there should be a critical friendship between professors and students. 


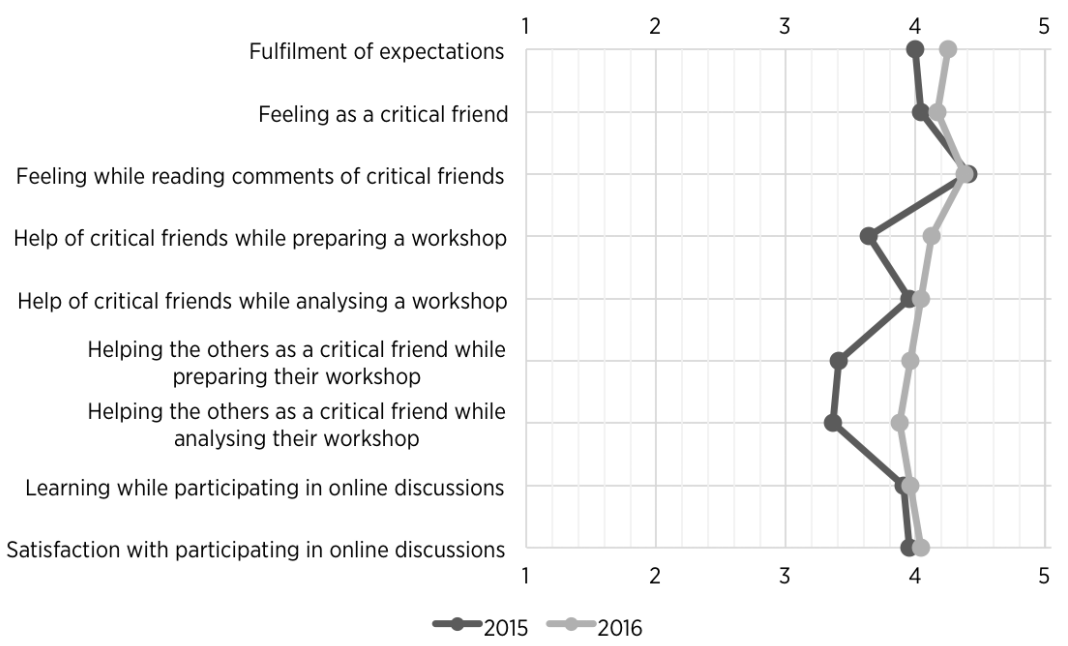

Figure 5. Differences between the first and the second years of research in the answers to the closed-type questions.

From Figure 5 it can be observed that the second year of research shows either similar or slightly higher average results to answers of the closed-type questions compared to the first year of research. Students are more satisfied with meeting their expectations, but also with the assistance of their critical friends to prepare for classroom activities, as well as with their own assistance to other teams in the preparing and the analysis of classroom activities. Students in both years were very satisfied with participating in the critical-friendly discussion on the web forum. Most students (91\%) think that critical-friendly discussions should be used in the future as a part of this course and that it should be incorporated into some other courses (85\%).

The responses obtained from students' interviews were more or less in line with the results from the evaluation questionnaire. However, in the interview students pointed out that the final discussion that was held after the workshops was unnecessary because they were mainly repeating what they had already written in the discussion that was held during the preparation stage for the workshops.

\section{Qualitative Analysis of Students' Discussions on the Online Forum}

The primary purpose of this action research was to encourage students to think reflectively by participating in the critical-friendly discussions on the web forum. In Figure 6, it can be seen that this goal was achieved. Namely, most of the communication on the forum represents a type of reflectivity on 
one's own work. The technical reflectivity dominates (63\%), followed by practical reflectivity (22\%), while critical reflectivity is very rare $(3 \%)$. In part of the communication, there was no reflectivity at all (13\%).

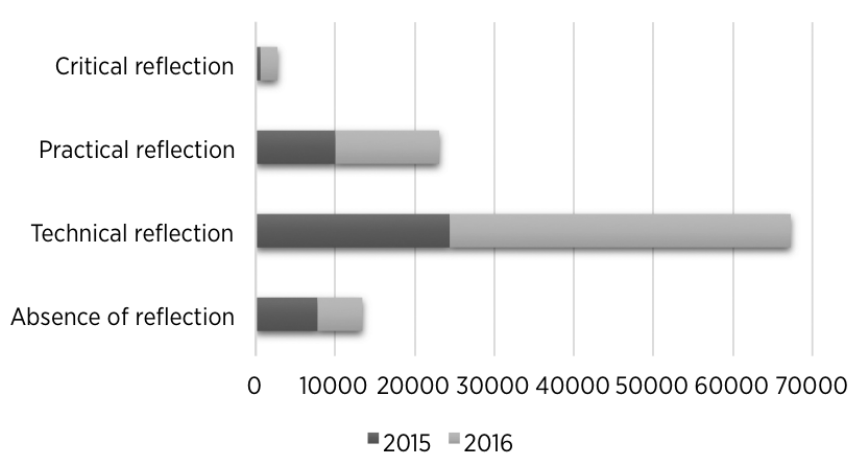

Figure 6. Relation between different types of reflectivity in two years of research represented in the number of written words

Technical reflectivity in students' discussions involved the organisational aspect of the workshops. Therefore, students were mainly writing about the activities, their implementations in the workshops, their arrangement and duration. Theoretical explanations are very rare in the discussions, aside from several references that mostly do not have a clear connection to the text itself:

Your topic really does have a wide spectrum of possibilities, and you have used that excellently to your advantage with many practical activities. It might be better if you had planned the poster for the Arts course instead of the mind map for the Science course. At least that is the case in my school where pupils use mind maps for revision at the end of every class, and the children are fed up with it. (Student V.P., personal communication, May 3, 2015)

Practical reflectivity included the interconnection between theory and practice. In this case, the theoretical explanations had a clear connection with the text and showed a deeper understanding of the topic. The discussion was intended to promote thinking about goals, and not only about activities. Therefore, the possibility of creating student-centred teaching was scrutinised:

I believe that we all know that contemporary teaching, i.e. student-centred teaching is extremely important for a student's progress. Furthermore, we all know from experience that teachers are still afraid of this 
type of teaching because they think it is difficult to implement in their own practice... Preparation for contemporary teaching is more difficult than preparation for traditional teaching, but the aftermaths of that type of work are, for me, much more valuable. Perhaps even because of these types of workshops that we have been participating in the Correlated-integrated systems in Croatian language teaching course and Methodology of education course, ${ }^{6}$ we will become the generation of teachers that will make changes in our own teaching. (Student I.S., personal communication, April 28, 2016)

Unlike technical reflectivity, which was found in every team's discussion regarding the realised workshops, practical reflectivity was not found in three out of eight team discussions after workshops in the first year. The second year's practical reflectivity was found in all team discussions before and after the workshops, although not with an equal ratio. It ranged from $2 \%$ to $38 \%$.

For critical reflectivity, which was very rare in the discussions, it is important to put teaching in a wider social context. Critical reflectivity includes re-questioning the socio-political problems and the distribution of power that inhibit people from developing their productive potential. It is important to mention that in the first year of research, critical reflectivity was found only in one out of eight discussions, while in the second year it was found in two out of six. This type of reflectivity was mainly connected to the discussion regarding the status of women in society. One member of the team, whose workshop topic was the status of women in society, commented on the role of women in another team's workshop:

When we look at the content of the fairy tale Snow White, we can also see that the female status is jeopardised. I might be wrong, but I am not sure how many women would joyfully cook and sing for seven or more people and how many women would enjoy cleaning after others. We know that children identify with the main character who eventually becomes their role model. However, I am not sure if it is a good idea that their role model is a naive woman who does all the household chores and who is only admired for her beauty. (Student I.P., personal communication, April 29, 2016)

However, that comment did not prompt the other team, whose topic was the fairy tale Fisherman Palunko and His Wife, to reconsider their goals and planned activities for the workshop.

6 This course is led by the first author of this article 


\section{Discussion}

The first time that students participated in discussions of critical friends in online forums was in the last year of their study. Most of them embraced participation in such organised discussions with delight, while a few of them resisted or simply did not participate at all. Negative reactions of some students were the most evident in the first year of research. To increase students' satisfaction with online discussions of critical friends, several improvements were made in the Moodle course (better organised and explained tasks in the Moodle course), as well as in the organisation of the whole process (extended time for discussions). A particularly important improvement was using videos of workshops recorded in the previous year in the classroom teaching and in the Moodle course. Thus, workshops that students should prepare and carry out gained increased importance. They were not utilised only for the practical assessment of students' learning, but they became teaching resources available for future generations of students.

Despite these improvements, increased activity and satisfaction of most students, two students did not enter a discussion at all in the second year of research, while two participated only in the first part. It is obvious that this type of written communication is not convenient for all students. Since written communication is a vital precondition for future teachers, it would be necessary to include students in various online activities from the beginning of their study to help them develop writing and reflective skills.

Online discussions of critical friends were encouraging for cooperative learning, and the teacher's role turned more into the role of a facilitator who was responsible for providing organisational and technical support to students. Students obtained everything else independently. They relied on members of their teams during the planning, preparing and realisation of workshop activities, while critical friends helped with their comments in the online forums. Although such organised discussions of critical friends contributed to the cooperative learning of students, we cannot conclude that they contributed to devising creative workshop activities. Comments of critical friends were rather encouraging, and positive feedback confirmed that everything was well planned and successfully carried out. It indicates that we need to make progress in students' reflective thinking, which was mostly at the technical level.

Although it is not possible to avoid technical reflectivity in the everyday practices of a teacher, it is important to enable students to gain more advanced levels of reflectivity. This refers particularly to their critical reflection. Brookfield emphasises its two main aims:

The first is to understand how considerations of power undergird, frame, and distort education processes and interactions. The second 
is to question assumptions and practices that seem to make our teaching lives easier but actually work against our own long-term interests. (Brookfield, 1995, p. 8)

However, it is hardly possible to expect that critical and self-critical thinking will happen in the education of future teachers that does not allow enough opportunities for its developing and is more oriented to practicing teaching methods (Peko, Mlinarević, \& Buljubašić-Kuzmanović, 2008). To make changes possible, it is necessary that professors empower their reflective capacities and work collaboratively to improve their practices. Participative action research in higher education could contribute to achieving this aim (Wood, Seobi, Setlhare-Meltor, \& Waddington, 2015). Inviting students to be critical friends and co-researchers in the action research of their professors was suggested by one student. We consider this to be a good practice.

Our collaborative action research resulted in introducing critical friendship into the course. It induced the activity, cooperation, and reflectivity of students. In addition, it contributed to the learning process. During personal conversation, the second author of this paper said that she encountered the term critical reflection for the first time while she participated in our action research: 'It was for me, in some way, a fantastic discovery that I can go further and deeper in my own work. However, our cooperation was necessary for such change to happen since it opened some new perspectives for her. She pointed out that no one is able to make innovations on their own: 'One has to be impelled by something, with new insights. That is why cooperation, contacts and critical reflection is important. Simply it is not possible to be without it' (I. Krumes, personal communication, February 24, 2017).

Online discussion of critical friends represents a way of encouraging students' critical reflective thinking. It could be combined with a face-to-face classroom discussion that was suggested by students. They also suggested synchronous communication over Skype or some other online application to make a discussion more dynamic. In further attempts, we intend to organise only one discussion after workshops. In that way, we could avoid repetition in their discussions, which students emphasised to be a problem. It also could reduce the time for participating in such activities, which students had also noted as a disadvantage. However, shortening the time for learning should not be the ultimate goal. The reason we initiated this research was our dissatisfaction with the quality of previous classroom discussions about teaching. We are aware that students participating in discussions spent a lot of time reading and writing their comments and studying professional literature. However, we consider that 
this is to be precisely the level of learning appropriate for the last year of university study. Students were also aware of this and they suggested a continuation of online discussions of critical friends in this course and introducing this practice into other courses, particularly in different teaching methodologies.

We realised that it is not enough to give students an opportunity to participate in critical-friendly discussions in the online forum and expect that they will eventually reach a higher level of reflectivity. They need the support of their teachers (Liu, 2013). In our case, it appeared that a socially engaged topic like the role of women in society prompted the most critical-reflective comments. Students selected this topic by themselves, as well as all other topics. The problem was that just one of 14 teams chose such a topic over the two years. This means that 'future teachers need considerable guidance and support to think critically about their experiences in schools and, especially, about the cultural biases they bring to those experiences' (Whipp, 2003, p. 322). Teachers need to encourage students to compare and contrast various ideas, question 'taken for granted beliefs and values', and view situations problematically (Bold \& Hutton, 2007, p. 27).

It is important to attempt to encourage students to develop critical reflectivity based on the presumption that 'educational practice is not simply instrumental in the sense of figuring out how to get things done, but also and more importantly, it is social and political in the sense of deliberating about what to get done and why, who decides, and whose interests are served' (Cochran-Smith \& Lytle, 2009, p. 121). However, the practical/contextual reflectivity should not be neglected since it contributes to deeper understanding of everyday practice that is not possible to achieve from the perspective of either critical, or technical reflectivity. Specifically, each teaching situation is unique and it is possible to understand it if we are theoretically well equipped and if we understand our professional context well. Coimbra, Martins, Pinto and Duarte point out that 'the essence of practical reflectivity is set on the group's interpretation of every day pedagogical experiences and on collaborative work, as paths of creation of the learning community' (2014, p. 186).

Finally, we agree with van Mannen that reflective thinking is not the only precondition of teacher's artistry. Moreover, 'if teachers were to try to be constantly critically aware of what they were doing and why they were doing these things, they would inevitably become artificial and flounder' (1995). He believes that teachers should develop the pedagogical tact that implies spontaneous and creative reactions in unique educational situations. Future teachers could look to their professors in developing their artistry. However, they could also learn from their own experiences in the workshops. Videos of their 
teaching attempts could be helpful in developing their professional skills:

'I as well as my colleague S. thought that our studies are coming to an end. This is why all those workshops left a deep mark on us... They will remain indelibly embedded in our memories thanks to videos and photos.' (Student M. A., personal communication, May 24, 2016)

\section{Conclusion}

Critical thinking is an essential life skill in $21^{\text {st }}$-century democratic society (World Economic Forum, 2015). With the aim of fostering the development of critical thinking in their students, prospective teachers should develop their own critical and reflective thinking during their higher education. It is important to emphasise that 'no teacher education programme can prepare teachers for all the situations they will encounter. Teachers themselves will make the final decisions from among many alternatives' (Han, 1995). This is the reason that they should develop their reflectivity.

Articles that merely detect problems and plead for introducing critical thinking in teacher education cannot be of much help. Instead, professors as 'action researchers need to show their collective intent to live out the values which inform their work' (McNiff \& Whitehead, 2002, p. 25). In this action research, we enable our students to participate in online critical friends' discussions about workshops that they independently and cooperatively devised, prepared, and conducted. We found that it encouraged students' reflective thinking, although it was performed at the lowest (i.e. technical) level. This result is not satisfactory. We observed that critical reflection rose to the fore in the team that chose a socially engaged topic. We could conclude that dealing with such topics from the first year of their study could encourage students' critical reflective thinking. Therefore, we are going to apply this conclusion in our teaching practice. The meaningfulness of this decision is corroborated by the following opinion of one student:

We frequently hear that contemporary teaching, which we all aspire to, needs to teach pupils, among other things, critical thinking. How can we teach it to them when we as future teachers have rarely met with methods of critical thinking? This is why this is an excellent way to encourage us as future teachers, at least in this last fifth year, to reflect a bit. (Student 14, personal communication, June 11, 2015) 


\section{References}

Argyris, C., \& Schön, D. A. (1975). Theory in practice: Increasing professional effectiveness. San Francisco, CA: Jossey-Bass Publishers.

Bognar, B., \& Mompoint-Gaillard, P. (2017). Creating an online community of action researchers.

Strasbourg: Council of Europe Publishing.

Bognar, B., Gajger, V., \& Ivić, V. (2016). Constructivist e-learning in higher education. Croatian Journal of Education, 18(Sp. Ed. No. 1), 31-46.

Bognar, L., \& Matijević, M. (2002). Didaktika [Didactics]. Zagreb: Školska knjiga.

Bold, C., \& Hutton, P. (2007). Supporting students' critical reflection-on-practice. In A. Campbell, \&

L. Norton (Eds.), Learning, teaching and assessing in higher education: Developing reflective practice (pp. 21-30). Exeter, UK: Learning Matters.

Boud, D. (2001). Using journal writing to enhance reflective practice. New Directions for Adult and Continuing Education, 90, 9-18. doi:10.1002/ace.16

Bowles, S., \& Ginits, H. (2007). Broken promises: School reform in retrospect. In A. R. Sadovnik (Ed.), Sociology of education: A critical reader (pp. 53-69). New York: Routledge.

Brookfield, S. D. (1995). Becoming a critically reflective teacher. San Francisco, CA: Jossey-Bass. Brookfield, S. D. (2005). The power of critical theory for adult learning and teaching. New York: Open University Press.

Brookfield, S. D. (2006). The skillful teacher: On technique, trust, and responsiveness in the classroom.

San Francisco, CA: Jossey-Bass.

Brookfield, S. D. (2010). Critical reflection as an adult learning process. In N. Lyons (Ed.), Handbook of reflection and reflective inquiry (pp. 215-236). New York: Springer.

Carr, W., \& Kemmis, S. (1986). Becoming critical: Education, knowledge and action research. London: Routledge/Falmer.

Chambers, P., Colombo, M., Askland, L., \& Clarke, B. (2003). Significant learning incidents and critical conversations in an international context: Promoting reflexivity with in-service students. Journal of InService Education, 29(1), 101-122. doi:10.1080/13674580300200199

Cho, K., \& Schunn, C. D. (2003). Seven cognitiv factors that make learning successful in networked collaboration. In R. Alterman, \& D. Kirsch (Eds.), Proceedings of the 25 th Annual Cognitive Science Society: Part 1 and 2 (pp. 246-251). New York: Psychology Press.

Choy, S. C., \& Oo, P. S. (2012). Reflective thinking and teaching practices: A precursor for incorporating critical thinking into the classroom? International Journal of Instruction, 5(1), 167-182.

Cochran-Smith, M., \& Lytle, S. L. (2009). Inquiry as stance. New York, NY: Teachers College Press. Coimbra, M. N., Martins, A. O., Pinto, I. P., \& Duarte, R. S. (2014). Practical reflectivity as a context for teachers' professional development: A mixed-methods study. Advances in Social Sciences Research Journal, 1(8), 176-187. doi:10.14738/assrj.18.746

Costa, A., \& Kallick, B. (1993). Through the lens of a critical friend. Educational leadership, 51(2), 49-51.

Craig, C. J. (2009). Learning about reflection through exploring narrative inquiry. Reflective Practice, 
10(1), 105-116. doi:10.1080/14623940802652920

Dewey, J. (1910). How we think. Boston: D. C. Heath.

Dougiamas, M., \& Taylor, P. C. (2003). Moodle: Using learning communities to create an open source course management system. World Conference on Educational Multimedia, Hypermedia and Telecommunications (EDMEDIA) 2003. Chesapeake, VA, USA.

Ennis, R. H. (1993). Critical thinking assessment. Theory into practice, 32(3), 179-186.

Fook, J. (2015). Reflective practice and critical reflection. In J. Lishman (Ed.), Handbook for practice learning in social work and social care (pp. 440-454). London: Jessica Kingsley Publishers.

Fook, J., \& Askeland, G. A. (2006). The 'critical' in critical reflection. In S. White, J. Fook, \& F. Gardner (Eds.), Critical reflection in health and social care (pp. 40-53). New York, NY: Open University Press. Fook, J., \& Askeland, G. A. (2007). Challenges of critical reflection: 'Nothing ventured, nothing gained'. Social Work Education, 26(5), 520-533. doi:10.1080/02615470601118662

Fook, J., \& Gardner, F. (2006). Critical reflection: A review of contemporary literature and understandings. In S. White, J. Fook, \& F. Gardner (Eds.), Critical reflection in health and social care (pp. 3-20). Maidenhead: Open University Press.

Gay, G., \& Kirkland, K. (2003). Developing cultural critical consciousness and self-reflection in preservice teacher education. Theory into practice, 42(3), 181-187. doi:10.1207/s15430421tip4203_3 Griffin, M. L. (2003). Using critical incidents to promote and assess reflective thinking in preservice teachers. Reflective Practice, 4(2), 207-220. doi:10.1080/14623940308274

Habermas, J. (1971). Knowledge and human interests. (J. J. Shapiro, Trans.) Boston: Beacon Press. Habermas, J. (1974). Theory and practice. Boston, MA: Beacon Press.

Han, E. P. (1995). Reflection is essential in teacher education. Childhood Education, 71(4), 228-231. doi:1 $0.1080 / 00094056.1995 .10522606$

Haralambos, M., \& Holborn, M. (2002). Sociologija: Teme i perspektive [Sociology: Themes and perspectives]. Zagreb: Golden marketing.

Harrington, H. L., \& Hathaway, R. S. (1994). Computer conferencing, critical reflection, and teacher development. Teaching \& Teacher Education, 10(5), 543-554.

Hattie, J. (2015). What works best in education: The politics of collaborative expertise. London: Pearson. Hernandez, F., \& Endo, R. (2017). Developing and supporting critically reflective teachers. In F. Hernandez, \& R. Endo (Eds.), Developing and supporting critically reflective teachers (pp. 1-16). Rotterdam: Sense Publishers.

Horkheimer, M. (1989). Critical theory: Selected essays. New York, NY: Continuum.

Ingvarson, L., Meiers, M., \& Beavis, A. (2005). Factors affecting the impact of professional development programs on teachers' knowledge, practice, student outcomes \& efficacy. Education Policy Analysis Archives, 13(10), 1-28. doi:10.14507/epaa.v13n10.2005

Kemmis, S., McTaggart, R., \& Nixon, R. (2014). The action research planner: Doing critical participatory action research. London, UK: Springer.

Kincheloe, J. (1995). Meet me behind the curtain: The struggle for a critical postmodern action research. In P. L. McLaren, \& J. Giarelli (Eds.), Critical theory and educational research (pp. 71-89). New York: 
State University of New York.

Lewis, L. (2015). A critical reflection on eportfolio as a teaching tool. New Zealand Journal of Teachers'

Work, 12(2), 115-130.

Liu, K. (2013). Critical reflection as a framework for transformative learning in teacher education.

Educational Review, 67(2), 135-157. doi:10.1080/00131911.2013.839546

MacKnight, C. B. (200o). Teaching critical thinking through online discussions. Educase Qarterly, 23(4), 38-41. Retrieved from http://er.educause.edu/ /media/files/article-downloads/eqmoo48.pdf McNiff, J., \& Whitehead, J. (2002). Action research: Principles and practice. London, UK: Routledge/ Falmer.

McNiff, J., \& Whitehead, J. (2010). You and your action research project. (3rd ed.). London: Routledge. Mezirow, J. (2000). Learning to think like an adult: Core concepts of transformation theory. In J.

Mezirow, \& Associates (Eds.), Learning as transformation (pp. 3-33). San Fancisco, CA: Josey-Bass. Nadin, S., \& Cassell, C. (2006). The use of a research diary as a tool for reflexive practice: Some reflections from management research. Qualitative Research in Accounting \& Management, 3(3), 208-217. doi:10.1108/11766090610705407

Peko, A., Mlinarević, V., \& Buljubašić-Kuzmanović, V. (2008). Potreba unaprjeđivanja sveučilišne nastave [The need for improvement of instruction at university level]. Odgojne znanosti, 10(1), 195-208. Retrieved from http://hrcak.srce.hr/28685

Phan, H. P. (2010). Critical thinking as a self-regulatory process component in teaching and learning. Psicothema, 22(2), 284-292.

Porntaweekul, S., Raksasataya, S., \& Nethanomsak, T. (2015). Development of the reflective thinking instructional model for student teachers. International Forum of Teaching and Studies, 11(1-2), 24-32. Prensky, M. (2001). Digital natives, digital immigrants. On the Horizon, 9(5), 2-6.

doi:10.1108/10748120110424816

Rosandić, D. (2005). Metodika književnog odgoja: Temeljci metodičkoknjiževne enciklopedije [Literature education methodology: Encyclopedia of literature and methodology fundamentals]. Zagreb: Školska knjiga.

Scales, P., Briddon, K., \& Senior, L. (2013). Teaching in the lifelong learning sector. Maidenhead: Open University Press.

Schein, E. H. (2010). Organizational culture and leadership. (4th ed.). San Francisco: Jossey-Bass. Schön, D. A. (1983). The reflective practitioner: How professionals think in action. New York: Basic Books. Schön, D. A. (1987). Educating the reflective practitioner. San Francisco: Jossey-Bass.

Shandomo, H. M. (2010). The role of critical reflection in teacher education. School-University Partnerships, 4(1), 101-113. Retrieved from http://files.eric.ed.gov/fulltext/EJ915885.pdf Smith, E. (2010). Teaching critical reflection. Teaching in Higher Education, 16(2), 211-223. doi:10.1080/1 3562517.2010 .515022

Stoll, L. (1998). School culture. School Improvement Network's Bulletin, 9, 9-14.

Taggart, G. L., \& Wilson, A. P. (2005). Promoting reflective thinking in teachers: 50 action strategies. (2. ed.). Thousand Oaks: Corwin Press. 
Težak, S. (1996). Teorija i praksa nastave hrvatskog jezika 1 [Theory and practice of Croatian language teaching 1]. Zagreb: Školska knjiga.

Tsang, A. K. (2011). Online reflective group discussion - connecting first year undergraduate students with their third year peers. Journal of the Scholarship of Teaching and Learning, 11(3), 58-74. Retrieved from https://josotl.indiana.edu/article/view/1828/1825 van Manen, M. (1977). Linking ways of knowing with ways of being practical. Curriculum Inquiry, 6(3), 205-228.

van Manen, M. (1995). On the epistemology of reflective practice. Teachers and Teaching: theory and practice, $1(1), 33-50$.

Vidović, S., \& Kuharić Bučević, V. (2013). The enhancement of creativity in Technical Education. Educational Journal of Living Theories, 6(1), 57-85. Retrieved from http://ejolts.net/node/204 Vince, R., \& Reynolds, M. (2009). Reflection, reflective practice and organizing reflection. In S. J. Armstrong, \& C. V. Fukami (Eds.), The SAGE handbook of management learning, education and development (pp. 89-103). Los Angeles: SAGE.

Whipp, J. L. (2003). Scaffolding critical reflection in online discussions: Helping prospective teachers think deeply about field experiences in urban schools. Journal of Teacher Education, 54(4), 321-333. Wood, L., Seobi, A., Setlhare-Meltor, R., \& Waddington, R. (2015). Reflecting on reflecting: Fostering student capacity for critical reflection in an action research project. Educational Research for Social Change, 4(1), 79-93.

World Economic Forum (2015). New vision for education: Unlocking the potential of technology. Geneva, Switzerland. Retrieved from http://www3.weforum.org/docs/WEFUSA_NewVisionforEducation_ Report2015.pdf

\section{Biographical note}

Branko Bognar, PhD, Associate Professor at the Faculty of Education, Josip Juraj Strossmayer University in Osijek where he teaches Pedagogy, Methodology of educational activities, and Pedagogical research methodology. His main professional interest is connected with introducing changes into educational practice with the aim of breaking the boundaries of traditional teaching. Accordingly, he endeavours to promote the idea of action research in Croatian educational context and abroad by using web-based technologies and e-learning particularly. In addition, he puts emphasis on development of teachers' and students' creativity and creative approach to science.

Irena Krumes, PhD, Assistant Professor at the Faculty of Education, Josip Juraj Strossmayer University in Osijek with professional interests in diachronic linguistics, lexicography and lexicology, the history of the Croatian language, the language and literacy development in children, language education, and e-learning. She teaches Croatian language teaching methodology, Correlated-integrated systems in Croatian language teaching, and Children's literature. 